\title{
PENGARUH PEMBERIAN BIMBINGAN \\ KELOMPOK TERHADAP PENINGKATAN MOTIVASI BELAJAR SISWA PADA SISW SDN 2 KELAYU JORONG
}

\author{
M. Deni Siregar \\ Universitas Hamzanwadi \\ Email: muhammaddenisiregar@gmail.com
}

\begin{abstract}
Abstrak
Penelitian ini bertujuan untuk mengetahui seberapa besar pengaruh pemberian bimbingan kelompok dalam terhadap motivasi belajar siswa pada SDN 2 Kelayu Jorong. Dalam penelitian ini peneliti menggunakan penelitian eksperimen sungguhan dengan jenis control group pre-test pos-test. Teknik pengumpulan data disesuaikan dengan hasil yang ingin dicapai dalam penelitian. Instrument yang akan digunakan dalam pengumpulan data yaitu menggunakan angket dan observasi. Untuk mengetahui apakah layanan bimbingan kelompok berpengaruh dalam kesulitan belajar, digunakan t-test dengan polled. Harga thitung 11,44. Adapaun dimana haraga t-hitung dibandingkan dengan t-tabel $(\mathrm{dk}=$ $\mathrm{n}_{1}+\mathrm{n}_{2}-2=30+30-2=58$ ). Berdasarkan $\mathrm{dk}=58$, untuk kesalahan $5 \%$, maka harga t-tabel $=2,000$. Ternyata harga t hitung $(11,44)$ lebih besar dari harga t-tabel $(11,44>2,000)$. Dengan demikian Ha diterima dan Ho ditolak. Kesimpulannya "Meningkatnya motivasi belajar dengan menggunakan bimbingan kelompok pada siswa SDN 2 Kelayu Jorong Tahun Pelajaran 2016/2017”. Ini disebabkan karena bimbingan kelompok membuat siswa untuk selalu aktif dalam setiap segi pembelajaran.
\end{abstract}

Kata Kunci : Bimbingan Kelompok dan Motivasi Belajar 


\section{PENDAHULUAN}

Pendidikan merupakan suatu yang terpenting demi kemaslahatan anak bangsa, karena pendidikan itulah letak kualitas suatu bangsa. Pendidikan dianggap berhasil apabila lulusannya mampu menempatkan dan mengembangkan dirinya sesuai dengan potensi yang dimilikinya dalam kehidupan bermasyarakat. Pada sekolah SD, kondisi siswanya termasuk kategori umur yang senang bermain-main, sehingga dalam tingkah lakunya cenderung untuk memperlihatkan identitasnya dalam bertingkah laku seperti: suka mencoba-coba, menyenangi hal-hal yang baru, ingin menang sendiri. Kondisi kejiwaannya masih sangat labil dan tingkah lakunya mudah berubah dan sangat emosional. Dalam menghadapi permasalahan, misalnya masalah belajar, masalah pribadi, masalah motivasi, masalah keluarga dan masalah ekonomi, yang mengakibatkan siswa mengalami perubahan yang tidak baik, seperti tidak percaya diri, prestasi belajar rendah yang akan mengakibatkan motivasi belajar rendah. Dengan layanan bimbingan dan konseling bantuan dapat diberikan oleh guru pembimbing sebagai guru konselor sekolah. Layanan bimbingan dan konseling yang digunakan adalah layanan konseling kelompok. Sebagai guru BK harus mampu memahami karakteristik siswa sehingga proses pemberian layanan BK sesuai dengan kebutuhan siswa itu sendiri. Guru BK dalam memberikan layanan kepada siswa yang bermasalah, misalnya masalah siswa itu sama, belum tentu cara pelayanannya akan sama pula dalam menyelesaikan masalahnya, tetapi disesuaikan dengan kebutuhan dan karakteristik siswa itu sendiri. Dalam mengembangkan kepribadiannya, anak didik banyak mengalami hambatan seperti motivasi belajar. Hambatan dapat datang dari dirinya sendiri maupun datang dari luar dirinya. Hambatan yang datang dari dirinya seperti: Rendahnya motivasi belajar, lambatnya menyerap pelayanan yang diberikan oleh guru, penggunaan waktu yang kurang efisien dan cara belajar yang kurang tepat. Dari luar dirinya seperti kurangnya perhatian orang tua terhadap pendidikan anak, tidak terpenuhinya kebutuhan anak dalam belajar, metode mengajar guru yang kurang relevan dengan apa yang diajarkannya, lingkungan tempat tinggal siswa yang tidak mendukung yang akan mengakibatkan siswa tidak berhasil dalam belajar. Kenyataan tersebut di atas, dialami siswa-siswa di SDN 2 Kelayu Jorong misalnya, motivasi belajar kurang, masalah pribadi, masalah sosial, masalah keluarga dan masalah ekonomi, 
yang mengakibatkan siswa mengalami perubahan yang tidak baik, seperti tidak termotivasi dalam belajar, prestasi belajar rendah yang akan mengakibatkan kesulitan dalam belajar, bentrok dengan guru, melanggar tata tertib sekolah, sukar menyesuaikan diri dalam belajar, suka berkelahi, jarang masuk sekolah, suka bolos sehingga dapat mengalami prestasi belajar yang rendah. Siswa SDN 2 Kelayu Jorong secara psikologis cenderung mengalami gejolak, baik faktor lingkungan keluarga, sekolah, dan masyarakat dapat mempengaruhi motivasi belajar mereka. Prayitno (1995: 178) mengemukakan bahwa Bimbingan kelompok adalah suatu kgiatan yang dilakukan oleh sekelompok orang dengan memanfaatkan dinamika kelompok. Dalam situasi dan kondisi seperti itulah guru BK di sekolah memberikan bantuan layanan bimbingan kelompok. Melalui layanan bimbingan kelompok guru BK secara langsung berada dalam kelompok tersebut, dan bertindak sebagai fasilitator (pemimpin kelompok) dalam dinamika kelompok yang terjadi, dengan menerapkan strategi pengembangan dan teknik-teknik bimbingan kelompok. Penelitian ini bertujuan untuk mengetahui seberapa besar pengaruh pemberian bimbingan kelompok dalam terhadap motivasi belajar siswa pada SDN 2 Kelayu Jorong.

\section{Bimbingan Kelompok}

Pada perinsipnya, bimbingan adalah suatu pertolongan atau tuntunan yang mengandung pengertian bahwa di dalam memberikan bantuan itu menjadi kewajiban bagi para pembimbing untuk memberikn bantuan kepada yang dibimbing. Bimbingan dapat diberikan baik untuk mengatasi masalah-masalah yang dihadapi oleh individu dalam kehidupan. Dari asal katanya, bimbingan merupakan terjemahan dari istilah "Guidance" dalam bahasa inggris. Sesuai dengan istilahnya, maka bimbingan dapat diartikan secara umum sebagai suatu "bantuan". Namun dalam pengertian yang sebenarnya tidak setiap bantuan adalah bimbingan. Bentuk bantuan dalam arti "bimbingan" membutuhkan syarat tertentu, bentuk tertentu, prosedur tertentu, pelaksanaan tertentu, sesuai dengan dasar prinsip dan tujuannya. Kegiatan bimbingan kelompok akan terlihat hidup jika didalamnya terdapat dinamika kelompok. Dinamika kelompok merupakan media efektif bagi anggota kelompok dalam mengembangkan aspek-aspek positif ketika mengadakan komunikasi antar pribadi dengan orang lain. Untuk mengetahui pengertian bimbingan kelompok, 
berikut ini dikemukakan beberapa pendapat para ahli. Prayitno (1995: 178) mengemukakan bahwa Bimbingan kelompok adalah suatu kgiatan yang dilakukan oleh sekelompok orang dengan memanfaatkan dinamika kelompok. Artinya, semua peserta dalam kegiatan kelompok saling berintraksi bebas mengeluarkan pendapat, menanggapi, memberi saran, dan lain-lain sebagainya; apa yang dibicarakan itu semuanya bermanfaat untuk diri peserta yang bersangkutan sendiri dan untuk peserta lainnya. Prayitno (1995: 61) berarti bimbingan kelompok adalah memanfaatkan dinamika untuk mencapai tujuan-tujuan bimbingan dan konseling. Bimbingan kelompok lebih merupakan suatu upaya bimbingan kepada individu-individu melalui kelompok. Jadi bimbingan kelompok adalah kegiatan yang dilakukan oleh kelompok yang memanfaatkan dinamika kelompok untuk mendapatkan manfaat dari padanya. Sukardi bimbingan kelompok (group guidance), ialah suatu teknik pelayanan bimbingan yang diberikan oleh pembimbing kepada sekelompok murid dengan tujuan membantu seseorang atau sekelompok murid yang mengahadapi masalahmasalah belajarnya dengan menempatkan dirinya di dalam suatu kehidupan/kegiatan kelompok yang sesuai. Prayitno (2001: 87-89) menyatakan layanan bimbingan kelompok adalah layanan bimbingan dan konseling yang memungkinkan sejumlah peserta didik secara bersama-sama melalui dinamika kelompok memperoleh berbagai bahan dari narasumber tertentu (terutama dari guru pembimbing) dan/atau membahas secara bersama-sama pokok bahasan (topik) tertentu yang berguna untuk menunjang pemahaman dan kehidupannya sebagai individu sebagai individu maupun sebagai pelajar, dan untuk pertimbangan dalam pengambilan keputusan dan/atau tindakan tertentu. Sedangkan menurut (Sukardi, 2003: 48) Layanan bimbingan kelompok dimaksudkan untuk memungkinkan siswa secara bersama-sama memperoleh berbagai bahan dari nara sumber (terutama guru pembimbing) yang bermanfaat untuk kehidupan sehari-hari baik sebagai individu maupun sebagai pelajar, anggota keluarga dan masyarakat. Dengan kegiatan layanan bimbingan kelompok diharapkan bukan saja sekedar mendapat pengetahuan, melainkan mengusahakan perubahan dalam sikap mereka dan dalam cara bergaul. Layanan bimbingan kelompok dapat diselenggarakan di mana saja, di dalam ruangan ataupun di luar ruangan, di sekolah atau di luar sekolah, di rumah salah satu peserta atau di rumah konselor. Di manapun layana bimbingan kelompok 
itu dilaksanakan, harus terjamin bahwa dinamika kelompok dapat berkembang dengan sebaik-baiknya untuk mencapai tujuan. Prayitno (2004:2-3) menyebutkan beberapa tujuan bimbingan kelompok yaitu: Tujuan umum layanan bimbingan kelompok adalah berkembangnya kemampuan sosialisasi siswa, khususnya kemampuan komunikasi peserta layanan. Dalam kaitan ini, sering menjadi kenyataan bahwa kemampuan bersosialisasi/ berkomunikasi seseorang sering terganggu oleh perasaan, pikiran, persepsi, wawasan dan sikap yang tidak objektif, sempit dan tidak efektif. Melalui layanan bimbingan kelompok hal-hal yang mengganggu atau menghimpit perasaan dapat diungkapkan, dilonggarkan, diringankan melalui berbagai cara, pikiran yang suntuk, buntu, atau beku dicairkan dan didinamikakan melalui masukkan dan tanggapan baru, peresepsi dan wawasan yang menyimpang atau semit diluruskan dan diperluas, pencairan pikiran, penyadaran dan penjelasan, sikap yang tidak objektif, terkungkung dan tidak terkendali, serta tidak efektif digugat dan didobrak, kalu perlu diganti dengan yang baru yaitu lebih efektif. Melalui kondisi dan peroses berperasaan, berfikir, berpersepsi dan berwawasan yang terarah, luas serta dinamis kemampuan berkomunikasi, bersosialisasi dan bersifat dapat dikembangkan. Bimbingan kelompok juga untuk mengentaskan masalah kelien dengan memanfaatkan dinamika kelompok. Winkel dan Sri Astuti dalam Nidya Damayanti (2012:41) menyebutkan tujuan layanan bimbingan kelompok menunjang perkembangan pribadi dan perkembangan sosial masing-asing anggota kelompok serta meningkatkan mutu kerja sama dalam kelompok guna aneka tujuan yang bermakna bagi para partisipan. Selain itu bimbingan kelompok bertujuan untuk merespon kebutuhan dan minat para peserta didik. Topik yang didiskusikan dalam bimbingan kelompok ini bersifat umum (common problem) dan tidak rahasia. Tohirin dalam Nidya Damayanti (2012:41) tujuan layanan bimbingan kelompok dikelompokkan menjadi dua yaitu tjuan umum dan tujuan khusus. Pertama adalah tujuan layanan bimbingan kelompok secara umum. Menurut beberapa pendapat ahli tersebut, dapat disimpulkan bahwa manfaat dari layanan bimbingan kelompok adalah dapat melatih kerjasama antara siswa dalam mengatasi masalah, melatih siswa untuk dapat mengemukakan pendapat dan menghargai pendapat orang lain dan dapat meningkatkan kemampuan siswa untuk dapat berkomunikasi dengan teman sebaya dan pembimbing. Beberapa jenis metode bimbingan kelompok menurut Tohirin yaitu 
: 1) Program Home Room, 2) Karyawisata, 3) Diskusi Kelompok, 4) Kegiatan Kelompok, 5) Organisasi Siswa, 6) Sosiodrama, 7) Psikodrama, 8) Pengajaran Remedial. Di dalam bimbingan kelompok terdapat kaidah-kaidah (asas-asas) yang harus diperhatikan, seperti :1) Asas kesukarelaan, 2) Asas kerahasiaan, 3) Asas keterbukaan, 4) Asas kenormatifan. Tahap pelaksanaan bimbingan kelompok menurut prayitno ada empat tahap yaitu : 1) Pembentukan, 2) Peralihan, 3) Kegiatan, 4) Pengahiran,

\section{Motivasi Belajar}

Asep Jihad (2009:01) mengatakan bahwa Belajar adalah kegiatan berproses dan merupakan unsur yang sangat fundemental dalam penyelenggaraan jenis dan jenjang pendidikan, hal ini berarati keberhasilan pencapaian tujuan pendidikan sangat tergantung pada keberhasilan proses belajar siswa di sekolah dan lingkungan sekitarnya. Pada dasarnya belajar merupakan tahap perubahan prilaku siswa yang relatif positif dan mantap sebagai hasil intraksi dengan lingkungan yang melibatkan proses kognitif (Syah, 2003). Slameto (1998: 54-72)Faktor-faktor yang mempengaruhi belajar banyak jenisnya, tetapi dapat digolongkan menjadi dua golongan saja, yaitu faktor intern dan faktor ekstren. Faktor intren adalah faktor yang ada dalam diri individu yang sedang belajar, sedangkan faktor ekstren adalah faktor yang ada di luar individu. 1) Faktor-Faktor Intren yaitu: a) Faktor Jasmaniah,b) Faktor Psikologis, c) Faktor Kelelahan, 2) Faktor-Faktor Ekstern yaitu: a) Faktor Keluarga, b) Faktor Sekolah, c) Faktor Masyarakat. Menurut Gray (dalam Winardi, 2002) motivasi merupakan sejumlah proses, yang bersifat internal, atau eksternal bagi seorang individu, yang menyebabkan timbulnya sikap antusiasme dan persistensi, dalam hal melaksanakan kegiatan- kegiatan tertentu. Soemanto (1987) secara umum mendefinisikan motivasi sebagai suatu perubahan tenaga yang ditandai oleh dorongan efektif dan reaksi- reaksi pencapaian tujuan. Karena kelakuan manusia itu selalu bertujuan, kita dapat menyimpulkan bahwa perubahan tenaga yang memberi kekuatan bagi tingkahlaku mencapai tujuan,telah terjadi di dalam diri seseorang. Mohammad Asrori (2007:183) menyatakan bahwa motivasi dapat diartikan sebagai: 1) dorongan yang timbul pada diri seseorang, secara disadari atau tidak disadari, untuk melakukan suatu tindakan dengan tujuan tertentu; 2) usaha-usaha yang dapat menyebabkan seseorang atau kelompok orang 
tertentu tergerak melakukan sesuatu karena ingin mencapai tujuan yang ingin dicapai. Mohammad Asrori (2007:184) menyatakan bahwa Dari dua definisi motivasi di atas, menjadi jelas baahwa motivasi dapat dibagi menjadi dua jenis, yaitu: 1) Motivasi yang berasal dari dalam diri seseorang. Motivasi jenis ini seringkali disebt dengan istilah motivasi intrinsik. Misalnya, seseorang siswa, tanpa disuruh oleh siapapun, setiap malam membaca buku pelajaran yang esok harinya akan dijelaskan oleh gurunya. 2) Motivasi dari luar yang berupa usaha pembentukan dari orang lain. Motivasi jenis ini seringkali disebut motivasi ekstrinsik. Misalnya: seorang yang biasanya kurang rajin belajar kemudian menjadi rajin belajar karena gurunya menjanjikan kepada siapa saja yang memperoleh nilai terbaik pada mata pelajaran yang diajarnya akan diberikan tiga seri buku cerita hari porter. Diatas telah dibahas macem-macem motivasi. Bahwa motivasi itu ada dua macam, yaitu motivasi intrinsik dan motivasi ekstrinsik. Hal-hal yang dapat menimbulkan motivasi intrinsik adalah: 1) Adanya Kebutuhan, 2) Adanya Pengetahuan Tentang Kemajuan Sendiri, 3) Adanya Aspirasi atau Cita-cita. Adapun hal-hal yang dapat menimbulkan motivasi ekstrinsik adalah: a) Ganjaran, b) Hukuman, dan c) Persaingan. Sudah jelas bahwa persaingan ini mempunyai insentif yang penting dalam pengajaran. Apabila persaingan diadakan dalam suasana yang fair, maka hal ini merupakan motivasi. Motivasi belajar merupakan suatu dorongan yang ada pada setiap individu yang membutuhkan proses dan usaha yang dilakukan untuk memperoleh hasil belajar yang baik . Dalam proses belajar ini berhasil atau tidaknya pelaksanaan proses tersebut sangat di pengaruhi oleh banyak hal. Yang dimana faktor yang mempengaruhinya itu bisa datang dari dirinya sendiri dan bisa juga datang dari orang lain. Hipotesis adalah dugaan sementara. Berdasarkan permasalahan dan kerangka berfikir yang telah diuraikan sebelumnya serta didukung oleh literatur dan kajian empirik yang relevan, hipotesis penelitian ini dapat dirumuskan hipotesis penelitian ini yaitu : "Layanan Bimbingan Kelompok Dapat Berpengaruh Dalam Mengatasi Masalah Rendahnya Motivasi Belajar Siswa Pada Kelas VII SMP Negeri 4 Pringgabaya Tahun Pelajaran 2016/2017".

\section{METODELOGI PENELITIAN}

Penelitian yang digunakan oleh peneliti adalah penelitian eksperimen. 
"Eksperimen dapat diartikan sebagai metode penelitian yang digunakan untuk mencari pengaruh perlakuan tertentu terhadap yang lain dalam kondisi yang terkendalikan" (Sugiyono 2010:72). Dalam penelitian ini peneliti menggunakan penelitian eksperimen sungguhan dengan jenis control group pre-test pos-test. Dalam rancangan ini, kelompok eksperimen diberi pelakuan sedangkan kelompok kontrol tidak. Pada kedua kelompok diawali dengan pre-test, dan setelah pemberian perlakuan diadakan pengukuran kembali (post-test). (Arikunto, 2002:80). Sabjek penelitian ini adalah siswa-siswi SDN 2 Kelayu Jorong tahun pelajaran 2016/2017 yang mengalamin rendahnya motivasi belajar. Pelaksanaan penelitian ini dilaksanakan pada bulan Nopember 2016 sampai selesai. Alasan memilih sekolah ini sebagai tempat penelitian adalah karena peneliti sudah mengetahui keadaan dan karakteristik dari sekolah serta siswa di sekolah tersebut. Dalam sabjek penelitian ini juga terdapat populasi dan sampel penelitian yang dijelaskan sebagai berikut. Populasi menurut Sugiyono (2011:117) adalah wilayah generalisasi yang terdiri atas: obyek/subyek yang mempunyai kualitas dan karkteristik tertentu yang ditetapkan oleh peneliti untuk dipelajari dan kemudian ditarik kesimpulannya sedangkan populasi menurut Babiy (1983) dalam Sukardi (2007:53) adalah elemen penelitian yang hidup dan tinggal bersama-sama dan secara tioritis menjadi target hasil penelitian. Berdasarkan pendapat tersebut maka, populasi dalam penelitian ini adalah semua siswa SDN 2 Kelayu Jorong Tahun Pelajaran 2016/2017. Dalam penelitian ini di lakukan di SDN 2 Kelayu Jorong dengan jumlah siswa 98 orang yaitu kelas VII ABC, adapun sampel penelitian di ambil 2 kelas pada kelas 4 dan 5. Pengambilan sampel dilakukan dengan cluster random sampling (diacak), sehingga didapatkan dua kelas yaitu kelompok 5 dan kelompok 4. kelompok 4 diajarkan dengan layanan bimbingan belompok sedangkan kelompok 5 diajarkan dengan pembelajaran konvensional. Sehingga sampel penelitian ini adalah 30 orang siswa. Teknik pengumpulan data disesuaikan dengan hasil yang ingin dicapai dalam penelitian. Instrument yang akan digunakan dalam pengumpulan data yaitu menggunakan angket dan observasi. Sebagai uji prasyarat analisis dilakukan uji normalitas dan uji homogenitas. Selanjutnya dari data yang diperoleh dianalisis dengan uji t. Untuk mengetahui apakah layanan bimbingan kelompok berpengaruh dalam kesulitan belajar, 
digunakan t-test dengan polled

\section{HASIL PENELITIAN DAN PEMBAHASAN}

Berdasarkan hasil analisis data menunjukkan t-hitung 11,44. Adapaun dimana haraga t-hitung dibandingkan dengan t-tabel $\left(\mathrm{dk}=\mathrm{n}_{1}+\mathrm{n}_{2}-2=30+30-2=58\right)$. Berdasarkan $\mathrm{dk}=58$, untuk kesalahan $5 \%$, maka harga t-tabel $=2,000$. Ternyata harga $t$ hitung $(11,44)$ lebih besar dari harga t-tabel $(11,44>2,000)$. Sehingga dapata menunjukkan peningkatan motivasi belajar dengan menggunakan bimbingan kelompok pada siswa SDN 2 Kelayu Jorong Tahun Pelajaran 2016/2017. Ini disebabkan karena bimbingan kelompok membuat siswa untuk selalu aktif dalam setiap segi pembelajaran, bimbingan kelompok ini merupakan suatu kegiatan kelompok yang dilakukan oleh sekelompok orang dengan memanfaatkan dinamika kelompok yakni adanya intraksi saling mengeluarkan pendapat,tanggapan, saran, dan sebagainya. Dengan demikian memudahkan para siswa dalam menyelesaikan setiap permasalahan yang didapatkan dalam memotivasinya dalam belajar. Bimbingan kelompok sangat bagus dalam membuat siswa dalam memajukan jiwa dalam berkompeisi sebagaimana Winkel dan Sri Astuti dalam Nidya Damayanti (2012:41) menyebutkan tujuan layanan bimbingan kelompok menunjang perkembangan pribadi dan perkembangan sosial masing-asing anggota kelompok serta meningkatkan mutu kerja sama dalam kelompok guna aneka tujuan yang bermakna bagi para partisipan. Selain itu bimbingan kelompok bertujuan untuk merespon kebutuhan dan minat para peserta didik. Topik yang didiskusikan dalam bimbingan kelompok ini bersifat umum (common problem) dan tidak rahasia. Tohirin dalam Nidya Damayanti (2012:41) tujuan layanan bimbingan kelompok dikelompokkan menjadi dua yaitu tjuan umum dan tujuan khusus. Pertama adalah tujuan layanan bimbingan kelompok secara umum. Secara umum layanan bimbingan kelompok bertujuan untuk pengembangan kemampuan bersosialisasi, khususnya kemampuan berkomunikasi peserta layanan (siswa). Kedua, tujuan layanan bimbingan kelompok secara lebih khusus layanan bimbingan kelompok bertujuan untuk mendorong pengembangan perasaan, pikiran, persepsi, wawasan dan sikap yang menunjang perwujudan tingkah laku yang lebih efekif, yaitu peningkatan kemampuan berkomunikasi baik verbal maupun non verbal para siswa. Dari beberapa pendapat di atas tujuan layanan 
bibingan kelompok adalah melatih siswa dalam mengembangkan kemampuan bersosialisasi, dan mewujudkan tingkah laku yang lebih efektif serta meningkatkan kemampuan berkomunikasi baik verbal dan non verbal. Siswa yang memiliki tujuan dalam belajar akan memiliki kesadaran dari dalam dirinya sendiri untuk dapat melaksanakan kegiatan belajar dengan harapan tujuan belajar yang diinginkan dapat tercapai. Untuk mencapai tujuan yang ingin dicapai, maka harus ada dorongan dari dalam diri individuitu sendiri. Menurut Gray (dalam Winardi, 2002) motivasi merupakan sejumlah proses, yang bersifat internal, atau eksternal bagi seorang individu, yang menyebabkan timbulnya sikap antusiasme dan persistensi, dalam hal melaksanakan kegiatan- kegiatan tertentu. Soemanto (1987) secara umum mendefinisikan motivasi sebagai suatu perubahan tenaga yang ditandai oleh dorongan efektif dan reaksi- reaksi pencapaian tujuan. Karena kelakuan manusia itu selalu bertujuan, kita dapat menyimpulkan bahwa perubahan tenaga yang memberi kekuatan bagi tingkahlaku mencapai tujuan,telah terjadi di dalam diri seseorang. Mohammad Asrori (2007:183) menyatakan bahwa motivasi dapat diartikan sebagai: 1) dorongan yang timbul pada diri seseorang, secara disadari atau tidak disadari, untuk melakukan suatu tindakan dengan tujuan tertentu; 2) usaha-usaha yang dapat menyebabkan seseorang atau kelompok orang tertentu tergerak melakukan sesuatu karena ingin mencapai tujuan yang ingin dicapai.

Penelitian ini didukung oleh penelitian lama yaitu Hasan, (2010). Melakukan penelitian dengan judul Pemberian Layanan Bimbingan Kelompok Dengan Menggunakan Media Untuk Meningkatkan Perestasi Belajar IPS Pada Kelas VI MI Tembeng Putik, dengan hasil yaitu melalui penerapan siklus 1 dan 2, dimana pada siklus 1 diperoleh hasil evaluasi menunjukkan perubahan positif pada perstasi belajar siswa yaitu dari katagori rendah menjadi sedang yaitu sebesar $50 \%$. Sedangkan pada siklus 2 perstasi belajar siswa meningkat dari katagori sedang menjadi tinggi yaitu meningkat menjadi 90\%. Berdasarkan pembahasan di atas dapat di katakan bahwa bimbingan kelompok sangat efektif dalam meningkatkan motivasi belajar siswa

\section{SIMPULAN}

Berdasarkan hasil penelitian dan analisa data yang sudah dilakukan, Berdasarkan hasil analisis data diatas, menunjukkan harga t-hitung dibandingkan 
dengan $\mathrm{t}$-tabel $\left(\mathrm{dk}=\mathrm{n}_{1}+\mathrm{n}_{2}-2=30+30-2=58\right)$. Berdasarkan $\mathrm{dk}=58$, untuk kesalahan $5 \%$, maka harga $\mathrm{t}$-tabel $=2,000$. Ternyata harga t hitung $(11,44)$ lebih besar dari harga t-tabel $(11,44>2,000)$. Sehingga dapata menunjukkan peningkatan motivasi belajar dengan menggunakan bimbingan kelompok pada siswa SDN 2 Kelayu Jorong Tahun Pelajaran 2016/2017. Ini disebabkan karena bimbingan kelompok membuat siswa untuk selalu aktif dalam setiap segi pembelajaran, bimbingan kelompok ini merupakan suatu kegiatan kelompok yang dilakukan oleh sekelompok orang dengan memanfaatkan dinamika kelompok yakni adanya intraksi saling mengeluarkan pendapat,tanggapan, saran, dan sebagainya. Dengan demikian memudahkan para siswa dalam menyelesaikan setiap permasalahan yang didapatkan dalam memotivasinya dalam belajar.

\section{DAFTAR PUSTAKA}

Ahmadi, Abu. 2008. Psikologi Belajar. Rineka Cipta: Solo

Ahmadi,Abu. 2007. Psikologi Sosial. PT Rineka Cipta: Semarang

Arikunto, Suharsimi. 2002. Prosedur Penelitian Suatu Pendekatan Praktek.Rineka Cipta: Jakarta.

Arikunto, Suharsimi. 2010. Prosedur Penelitian Suatu Pendekatan Praktek. Rineka Cipta: Jakarta.

Asrori, Mohammad. 2007. Psikologi Pembelajaran. CV Wacana Prima: Bandung

Damayanti, Nidya. 2012. Buku Pintar Panduan Bimbingan dan Konseling. Araska:

Yogyakarta.Devito, Joseph A. 2011. Komunikasi Antar Manusia Edisi Kelima. Karisma Publishing Group: Tangerang Selatan.

Hasan (2010) Pemberian Layanan Bimbingan Kelompok Dengan Menggunakan Media Untuk Meningkatkan Prestasi Belajar IPS Pada Kelas VI MI Tembeng Putik. Skripsi tidak diterbitkan. STKIP Hamzanwadi Selong.

Jihad, Asep. 2009. Evaluasi Pembelajaran. Multi Pressindo: Jakarta

Muliyadi. 2010. Diagnosis Kesulitan Belajar dan Bimbingan Terhadap Kesulitan Belajar Khusus. Nuha Litera: Malang

Prayitno dan Amti, Erman. 1994. Dasar-dasar Bimbingan dan Konseling. RinekaCipta: Jakarta 
Prayitno. 1995. Layanan Bimbingan Konseling Keompok. Balai Aksara: Padang

Sugiyono. 2010. Metode Penelitian Kuantitatif Kualitatif dan R \& D. Alfabeta : Bandung.

Sukardi, Dewa Ketut dkk. 2008. Proses Bimbingan dan Konseling di Sekolah. Rineka Cipta: Jakarta. 